eCommons@AKU

November 2017

\title{
Democratic engagement in the digital age: youth, social media and participatory politics in Kenya
}

Samuel Kamau

Aga Khan University, sam.kamau@aku.edu

Follow this and additional works at: https://ecommons.aku.edu/eastafrica_gsmc

Part of the Journalism Studies Commons, and the Mass Communication Commons

\section{Recommended Citation}

Kamau, S. (2017). Democratic engagement in the digital age: youth, social media and participatory politics in Kenya. Communicatio, 43(2), 128-146.

Available at: https://ecommons.aku.edu/eastafrica_gsmc/19 


\title{
Democratic engagement in the digital age: youth, social media and participatory politics in Kenya
}

\author{
Samuel C. Kamau
}

To cite this article: Samuel C. Kamau (2017) Democratic engagement in the digital age: youth, social media and participatory politics in Kenya, Communicatio, 43:2, 128-146, DOI: 10.1080/02500167.2017.1327874

To link to this article: https://doi.org/10.1080/02500167.2017.1327874

\section{曲 Published online: 22 Nov 2017.}

\section{Submit your article to this journal $\approx$}

LII Article views: 164

View Crossmark data ¿ 


\title{
DEMOCRATIC ENGAGEMENT IN THE \\ DIGITAL AGE: YOUTH, SOCIAL MEDIA AND PARTICIPATORY POLITICS IN KENYA
}

\author{
Samuel C. Kamau \\ Graduate School of Media and Communication \\ Aga Khan University, Kenya \\ kamau.samuel@aku.edu
}

\section{ABSTRACT}

As the communication world becomes more complex and participatory, social networking sites (SNSs) have emerged as a platform with the potential to invigorate democracy and political engagement. However, the value of SNSs in politics remains contested among researchers. The study reported on in this article was based on a survey of 600 university students, aged between 18 and 35 , to examine the relationship between social media use and political engagement among the youth in Kenya. The study focused on the extent to which SNSs facilitate consumption of political information and the role of SNSs in influencing political interest, knowledge and behaviour among the youth. The study found that reliance on SNSs is positively associated with political participation; however, this influence is limited, and though useful, it does not radically transform political engagement. Therefore, the capacity of SNSs to shape opinion and influence political preferences is limited but internet based political activities like posting and distributing campaign information and consumption of political content have a bearing on political participation. The study concluded that while SNSs do not seem to have a major direct impact on political choices among users, politicians and other campaign actors cannot ignore the opportunity provided by these platforms in the voter mobilisation process.

Keywords: social media; research; digital media; political communication; audience studies; new media technologies; journalism; digital activism

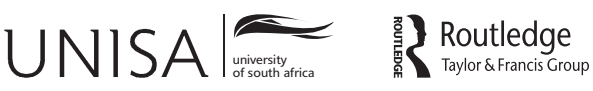




\section{INTRODUCTION}

Since former President of the United States (US) Barack Obama's successful use of social networking sites (SNSs) in his 2008 and 2012 campaigns (Smith 2009; 2013), coupled with the prominent role played by social media in the 2011 Arab spring (Storck 2011), SNSs have been considered by many to play a critical role in politics. In the 2016 US elections, SNSs played an even bigger role as the major candidates effectively exploited social media platforms to deliver their messages and mobilise voters. SNSs have emerged as tools with potential for promoting political participation and reenergising grassroots political mobilisation (Williams and Gulati 2008).

Recent studies have revealed that people, especially the youth, are increasingly turning to social media for information about politics. A recent study found that up to 61 per cent of millennials get their political news from Facebook and other SNS platforms (Mitchell, Gottfried and Matsa 2015). Beyond exposure to information, SNSs facilitate the sharing and exchange of political information among social media friends and connections.

While scholars are yet to agree on the extent of SNSs' influence on politics (Zhang, Johnson, Seltzer and Bichard 2010), there has been a growing recognition and acceptance of social media as important avenues and drivers of political engagement especially among the youth (Enjolras, Steen-Johnsen and Wollebaek 2010).

According to www.statista.com, as of August 2017, the global social network penetration was 31 per cent with 2.46 billion SNS users. Facebook was the most popular SNS with over 2.04 billion users followed by WhatsApp with 1.2 billion, and Twitter with 328 million. These new technologies have made the cyberspace more interesting and convenient for the users.

Internet access is growing steadily in Africa with 20 per cent of the African population having access (ITU 2015). Additionally, social media use in Africa is on the rise: by June 2015, Facebook had 120 million active users across Africa with 85 per cent using their mobile devices to access the platform (BBC Afrique 2015).

In 2014, Kenya was ranked fourth in Africa, in the use of social media and the internet, with 21 million internet users (Internet World Stats 2014). Kenya had about 6 million active Facebook users, and 700000 Twitter users according to a report by the Bloggers Association of Kenya (BAKE 2015). Additionally, 79 per cent of the Kenyan population was below the age of 35 and 70 per cent of those were eligible to vote (KNBS 2014).

\section{PROBLEM STATEMENT}

While there is no dispute over whether SNSs have a role to play in engaging young people in the political process, disagreement still exists on the level, nature and extent of that engagement. Smith (2013), and Williams and Gulati $(2007 ; 2008)$ have emphasised the effect of social media on voting behaviour while other scholars like Zhang et al. 
(2010) and Baumgartner and Morris (2009) have disputed this by downplaying the effect of SNSs on political engagement.

In the 2013 Kenyan elections, two presidential candidates who actively used social media during the presidential campaigns registered a dismal performance in the actual voting, despite overwhelming support on social media popularity ratings. Uhuru Kenyatta, who was eventually declared the winner in the presidential elections, had the most "liked" (followed) page on Facebook and the largest following on Twitter giving rise to suggestions that SNSs might have aided his voter mobilisation strategy.

New arguments have now emerged that social media could be killing democracy by facilitating the spread of fake news, toxic politics and creating political silos and bubbles, while also lowering the quality of debates.

\section{RESEARCH QUESTIONS}

The study sought to establish the relationship between social media usage and youth political engagement in Kenya and was guided by the following research questions (RQs):

RQ1: To what extent do social networking sites facilitate the spread or consumption of political information?

RQ2: What is the relationship between social media usage and political engagement among the youth?

RQ3: Do social networking sites influence political interest, knowledge and behaviour among the youth?

\section{MASS MEDIA AND PARTICIPATORY DEMOCRACY}

It has been argued that media consumption is related to political behaviour and scholars have attempted to establish how the usage of a particular mass medium stimulates political interest and the desire to participate in elections (Feldman and Kawakami 1991).

Political attitudes and opinions are formed through social interaction, political discussion and personal reflection. These processes are of a higher quality when people are exposed to dissimilar perspectives (Mutz and Martin 2001). Sunstein $(2002,205)$ argues that "democracy requires both a range of common experiences and unanticipated, unchosen exposures to diverse topics and ideas".

\section{SNSs, Communication and Society}

Šminas $(2010,235)$ defines social media as "interactive technologies and ways in which they can be used when individuals interact among themselves sharing the content they generated". SNSs, such as Facebook, Twitter and YouTube, have been 
widely embraced by a cross section of society, especially the youth (Boyd and Ellison 2007; Lenhart 2009), becoming important avenues for interpersonal communication (Thelwall, Wilkinson and Uppal 2009).

Social media have been credited with building connections among both heterogeneous groups and closely knit homogenous communities. Ellison, Steinfield and Lampe (2007) claim that users of SNSs primarily use the platform to connect with people they already know in real life, while Westling (2007) views the group function of SNSs as bringing users into contact with many people who are unknown to them.

Social media offer immediacy and interactivity in communication, two highly desirable attributes for young people, and now form a part of young adults daily routines (Steinfield, Ellison and Lampe 2008).

Perrin (2015) found that social media usage had experienced explosive growth between 2005 and 2015. Though it is mostly young people who use SNSs, there has been a rapid adoption among seniors (Perrin 2015). Social media now permeate every aspect of society from politics, work, communication habits, news consumption, to dating, among others (Shirky 2011).

\section{SNSs and Politics}

Researchers have found that the scope of communication about politics in the digital shared and interactive spaces is constantly increasing (Šuminas and Mierzecka 2014). An analysis of the use of SNSs for political purposes in the US in both the 2008 and 2012 revealed that reliance on SNSs sharply increased from 40 per cent in 2008 to 71 per cent in 2012 (Rainie and Smith 2012; Smith 2013).

Platforms such as Twitter enable users to perform a variety of political activities like posting, retweeting, quoting or replying to tweets about politics, and engaging politicians and political parties allowing users to participate in political debate (Tumasjan et al. 2010).

SNSs enable individuals to circumvent traditional gatekeepers, shifting political power to ordinary citizens and giving them voice and potential influence through their capacity to reach sizeable audiences in a simple inexpensive manner. These participatory acts through SNSs help to mobilise large audiences for specific causes, and help shape agenda through dialogue and the circulation of political information (Cohen and Kahne 2015).

Some scholars have investigated the role of social media and regime change following the revolutionary Arab Spring that swept across the Middle East (Safranek 2012). Stork (2011) and others have argued that the main role of SNS in the Arab Spring was to provide an "organisational infrastructure" as a form of alternative press to generate awareness and mobilise for collective action. 


\section{SNSs and Political Campaigns}

Hwang's (2016) study on political campaigning in the US observed that political candidates must learn how to use SNSs; go beyond marketing their brand; and garner a positive response that will translate into offline support. Hwang (2016) analysed Obama's two campaigns, noting that he was active on nearly twice as many platforms and generated nearly twice the responses compared to Romney.

Many people have acknowledged that Obama's campaign use of social media was a key factor in his election successes in 2008 and 2012 (Cornfield 2008; Zhang et al. 2010). He successfully raised over 80 per cent of his campaign donations through SNSs (Walmsley 2008).

Clarke $(2010,1)$ argues that politicians see social media as "a means to disseminate political messages, learn about the interests and needs of constituents and the broader public, raise funds and build networks of support". The ease of use has enabled campaigners to strategically target and customise their campaign messages and approaches to reach more people (Smith 2012; 2013). Through SNSs, politicians are able to personalise, customise and transmit messages directly to targeted audiences (Šuminas and Mierzecka 2014).

The 2016 US campaigns have recorded an increased adoption of SNSs (Mitchell, Gottfried and Matsa 2015). Hwang $(2016,117)$ argues that "whether the level of social media engagement will actually influence the outcome, participating in the available technology will expand the candidates' reach while maximising control of their campaign message".

\section{SNSs and Political Participation}

Cohen and Kahne $(2015,8)$ define participatory politics as "interactive, peer-based acts through which individuals and groups seek to exert both voice and influence on issues of public concern". They argue that the nexus between social media, youth and politics is not limited to America, but rather, it is international in scope as evidenced by events in Egypt, Tunisia and other parts of the Middle East (Cohen and Kahne 2015).

Significant debate still exists on whether SNSs can actually influence voter behaviour and political choice. Some studies have supported claims that SNSs create a new way of participating in politics especially for those who are traditionally disengaged from politics. By offering a low cost medium for citizens to participate in politics, social media removes the traditional barriers (Kushin and Yamamoto 2010; Tedesco 2007). Some studies have gone on to claim that in general elections context, social media use is a predictor of political participation especially voting (Gray, Vitak, Easton and Ellison 2013; Strandberg 2013).

Williams and Gulati (2008) investigated "online activity and vote share" and claimed that candidates in the 2006 US midterm elections marginally increased their 
vote share by increasing the number of Facebook supporters. However, their findings have largely been criticised as merely speculative without any empirical evidence.

Other studies have found that digital connectivity and interactivity can enhance political knowledge and political information efficacy leading to a better evaluation of a candidate (Gastil and Levine 2005; Tedesco 2007). Min (2007, 1369) found that that membership in SNSs correlates with increased "issue knowledge, political efficacy and willingness to participate in politics".

Multiple studies have also disputed the actual influence of SNSs on political participation. Zhang et al. (2010) did not find enough evidence to support claims that social media can influence voting preferences and behaviour. Bimber and Davis (2003) did not find any empirical evidence to prove that viewing a candidate's website had any impact on voting preference.

Baumgartner and Morris (2009) concluded in their study that "the contention that SN Web sites will spur a democratic revolution may be overstated" after they found that users of SNSs were no more knowledgeable about politics than their counterparts who did not use social media.

\section{Youth, Social Media and Politics}

Barbour et al. $(2013,46)$ note that "technology is second nature to young voters" and requires campaigns to utilise the newest and most cutting-edge social media platforms to engage this young generation.

Compared to the older generations, the youth are often viewed as less involved in politics (Bauerlein 2008). Delli Carpini (2000) found that the youth are less interested in politics or public affairs and less knowledgeable about the substance of politics. They care about their community, it is not in the political sense (Dalton 2008).

According to Baumgartner and Morris (2009), young adults who may not be interested in politics can get political information through their online network of friends and acquaintances, and this may generate greater political interest. The sense of "virtual community" can generate a greater interest around a political idea or leader.

Mitchell, Gottfried and Matsa (2015) found that digital sources (websites, apps and social media) were a major source of information about the 2016 campaigns only second to television. In their study looking at political news habits, Mitchell, Gottfried and Matsa (2015) found that 61 per cent of millennials (aged 18-33) got their news from Facebook - in stark contrast to 60 per cent their older counterparts who got their information from local television. 


\section{Social Media, Political Discourse and Habermas' Public Sphere Theory}

Habermas' (1962) public sphere theory envisions citizen deliberation being the catalyst of a rational public opinion which is a prerequisite for democracy. The ability of people to reason and speak freely in a shared social space devoid of political persecution or censorship is a key foundation of a democratic society (Habermas 1989). Political theorists agree that this is essential for a strong democracy to thrive (Dryzek 2000; Young 2000).

The Habermasian public sphere brings together all organs of political debate such as newspapers and journals, as well as institutions of political discussions such as parliaments, political clubs, literary salons, coffee houses, meeting halls and other spaces where social political discussions took place. Common public affairs are openly discussed giving the individuals power to shape public opinion (Habermas 1962; 1988; Kellner 1989).

Though very few societies if any, have ever achieved the discursive levels envisioned by Habermas, many people including his critics agree that his model provides a framework for solving political issues rationally by supporting "rational uncoerced discourse" (Gestrich 2006; Gimmler 2001).

Habermas focused on the discursive conditions of "rational discussion" anchored in face-to-face communication in interpersonal relations of everyday life (Calhoun 1992). The emphasis is on the formation of political will through the process of deliberative democracy undertaken through reflection, argumentation, public reasoning and consensus (Habermas in Kellner 2000).

Dewing (2010) and Westling (2007) view social media as a realisation and extension of Habermas' vision of a public sphere in which citizens form a public opinion that is not controlled by the government. In this sense, social media become a platform for members to engage in conversations with politicians and with each other on a variety of issues.

One key advantage of social media is their capacity to facilitate political discussions. Social media platforms facilitate the expression of diverse political views including minority and marginalised views (Clarke 2010; Zhang et al. 2010).

Westling (2007) argues that SNSs have the "potential to exceed Habermas' expectation of the public sphere" with their ability to combine the features of bulletin boards, newspapers, television and town hall meetings "in one location", thereby providing an outlet for young people to interpret political information and participate in political discussions. 


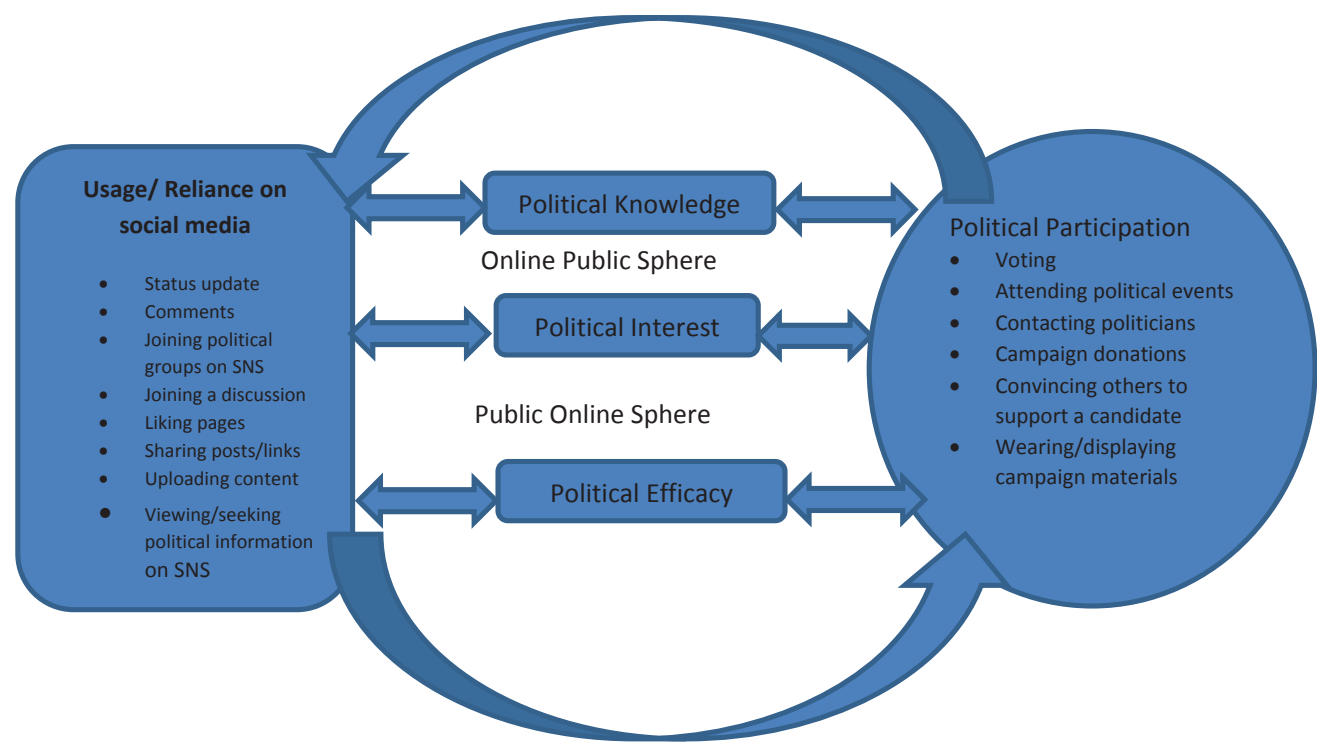

Figure 1: Conceptual framework

The diagram in Figure 1 approximates the relationship between reliance on SNSs and political participation. Political interactions and activities on social media platforms create an online public sphere in which political views are formed, shaped and shared. These interactions influence and are influenced by the users' political interest, knowledge and efficacy, which in turn have an influence on political participation.

\section{THE STUDY}

A survey was conducted of 600 social media users enrolled in two universities in Nairobi, Kenya. The respondents were selected through stratified random sampling by targeting students across different disciplines in the selected universities. Data was collected through self-reported questionnaires. The sample yielded 512 responses of which 53 per cent were female respondents and 47 per cent male respondents. The researcher also held five focus group discussions with social media users to augment the survey results. In February 2016, five more focus group discussions were held to update and compare the earlier findings.

\section{Dependent Variable}

Political participation: The nature and frequency of involvement in political activities; attending campaign events; contacting politicians; wearing and displaying campaign 
paraphernalia; voting; and persuading others to support a candidate or a political party. This was measured using an index of 13 items on a 6-point scale (Cronbach's alpha = $0.72)$.

\section{Independent Variable}

Reliance on social networking sites: The extent of individual users' attachment, use and dependence on SNS. This was measured by several items within the questionnaire $($ Cronbach's alpha $=0.85)$.

\section{Political Variables}

- Political interest: Refers to the level of attention paid to political news and events by an individual. It was measured by asking individuals to describe their interest in politics on a scale.

- Political efficacy: Refers to feelings of capacity to wield political influence. It was measured by an index of six items on a 5-point scale (Cronbach's alpha $=0.84)$.

- Political knowledge: Refers to level of knowledge about politics. It was measured by asking 12 factual questions about politics (Cronbach's alpha $=0.87$ ).

\section{Data Analysis Procedures}

After a basic descriptive analysis, a hierarchical regression analysis in which measurement was done at different levels of aggregation was done to let the researcher examine the extent to which the regression coefficients once different variables were applied. A correlation analysis was also performed to test the relationship between the variables.

\section{RESULTS}

\section{Exploring the Scope of Young People's Political Activity on Social Media}

The internet and social media are important sources of political information for young people at 51 per cent only behind television. A third of all those polled use SNSs to obtain political information at least four days in a week. Half of the respondents consider themselves reliant on SNSs with 20 per cent indicating they were heavily reliant thereon. 
Table 1 summarises the scope of political activity on social media among the youth over a three month period. More than half $(55 \%)$ of all the respondents indicated that they had engaged in the listed activities on SNSs.

Table 1: Scope of young people's political activity on social media

\begin{tabular}{|l|l|l|l|}
\hline In the last three months, did you ... & Yes \% & No \% & $\begin{array}{l}\text { Not } \\
\text { sure \% }\end{array}$ \\
\hline Come across information of a political nature on Facebook? & 91.0 & 4.7 & 2.1 \\
\hline Post information that is of a political nature on Facebook & 55.9 & 40.6 & 1.3 \\
\hline Join any group on Facebook that is political in nature? & 50.1 & 46.6 & 1.7 \\
\hline "Like" or join the Facebook page of a politician or political party? & 63.3 & 33.2 & 2.2 \\
\hline Engage in political discussions on social media? & 54.5 & 40.5 & 3.7 \\
\hline Invite a friend to join a political group on social media? & 18.2 & 78.1 & 2.2 \\
\hline Comment on another person's political post or status? & 69.2 & 26 & 2.2 \\
\hline Discover a new political event/occurrence on social media? & 61.4 & 31.5 & 5.8 \\
\hline $\begin{array}{l}\text { Follow a link of political story posted on YouTube, Facebook or } \\
\text { Twitter? }\end{array}$ & 60.8 & 33.5 & 3.7 \\
\hline Share another person's interesting political post? & 51.1 & 44.5 & 3.3 \\
\hline Watch a political video posted on YouTube, Facebook or Twitter? & 64.7 & 33.3 & 1.3 \\
\hline Share/upload a political video or photograph? & 32.8 & 64.6 & 1.5 \\
\hline Deliberately look for political information on social media? & 58.7 & 36.7 & 3.2 \\
\hline Total (Average) & $55 \%$ & $41 \%$ & $4 \%$ \\
\hline
\end{tabular}

\section{Social Media and Political Information}

Access and exposure to political information is a major strength of social media. Almost every young person using social media is exposed to political information whenever they $\log$ in (91\%). SNSs are an effective platform for absorption and dissemination of political news: 56 per cent of young people are actively involved in posting political information on SNSs and another 58.7 per cent actively seeking political information on media.

Facebook is major news powerhouse, 60.8 per cent of young people indicated they have followed a link to a political story after seeing it on Facebook. Many news outlets rely on Facebook as a major source of website referrals. Social media users use the sites to create, upload and share campaign information in the form of videos, photos among 
others. Further, they use the sites to discuss and engage with politicians and with each other on political issues without the traditional gatekeeping constraints.

\section{Political Discussions}

More than half of the youth surveyed (54\%) engage in frequent discussion of politics on SNSs. However, in the focus group discussions, most users indicated they found it difficult to debate objectively or engage in issue based discussions because of strong partisan positions that sometimes degenerate into personal attacks.

The group function on Facebook facilitates political discussions among members: 63.3 per cent of the respondents had liked or joined political groups and fan pages. However, most group members are usually passive and only consume information without contributing.

\section{Diversity of Opinion on Social Media}

SNSs facilitate exposure to information that is contrary to ones beliefs and opinion which is considered important in political decision making. Three quarters of the respondents $(74 \%)$ indicated that they had come across information that challenged their views and opinions. However, when people were exposed to information contrary to their beliefs, majority responded by ignoring $(61 \%)$, while the rest either deleted the message $(21 \%)$ or blocked or unfriended the person $(13 \%)$.

\section{Social Media, Political Decision Making and Opinion Formation}

The study found that information posted on social media plays a limited but significant role in influencing people's opinions and decisions. About two thirds indicated information posted on SNSs had never influenced their political decisions, while 27 per cent admitted they had changed their minds after reading or viewing something posted on social media. The focus group discussions revealed that people do not generally consider most of the political information on SNSs credible or serious. 


\section{The Influence of SNSs on Political Participation}

Table 2: Hierarchical regression analysis on the influence of SNSs on civic and political participation

\begin{tabular}{|l|l|l|l|l|l|}
\hline Model & Unstandardised & Coefficients & $\begin{array}{l}\text { Standardised } \\
\text { coefficients }\end{array}$ & $\mathbf{t}$ & Sig. \\
\hline & $\mathbf{B}$ & Std. Error & Beta & & \\
\hline Age & .128 & .099 & .052 & 1.295 & .196 \\
\hline Gender & .295 & .114 & .104 & 2.596 & .010 \\
\hline Level of education & -.008 & .008 & -.037 & -.940 & .348 \\
\hline Political knowledge & -.498 & .175 & -.118 & -2.847 & .005 \\
\hline Political efficacy & -.129 & .054 & -.098 & -2.414 & .016 \\
\hline Interest in politics & -.202 & .048 & -.198 & -4.244 & .000 \\
\hline $\begin{array}{l}\text { Interpersonal } \\
\text { discussion }\end{array}$ & .266 & .049 & .244 & 5.389 & .000 \\
\hline SNS reliance & .230 & .022 & .407 & 10.285 & .000 \\
\hline
\end{tabular}

\section{a. Dependent variable: Political participation}

The results from the hierarchical regression found a significant relationship between reliance on SNS and political participation $(\beta=0.41, p<0.001)$. The more people use SNSs to seek and share information and engage in political discussions, the more they are likely to participate in political activities.

A correlation analysis found a weak but significant positive correlation $(0.361, p$ $\leq 0.01$ ) between reliance on SNS and political participation. Focus group discussions confirmed that people who use and rely on SNS are more likely to participate in politics.

\section{Social Media and Political Interest, Knowledge and Efficacy}

About half (49\%) of those surveyed said they found politics interesting; 62 per cent said they pay attention to political news; and 18 per cent indicated they rarely pay attention to news touching on politics. However, compared to young women, young men exhibited a higher interest in politics and they pay more attention to political news than their female counterparts.

The study found a relatively high level of political knowledge among the surveyed youth. In responding to factual questions about politics, 51 per cent of the youth exhibited factual knowledge of politics and campaign information with young men scoring better (54\%) compared to the young women (47\%). 
In one of the intriguing findings of the study, the female respondents recorded a higher level of political efficacy than the male respondents: 45 per cent of all those polled believe they can influence both local and national government in some way, while 60 per cent believe their vote made a difference in the elections.

Table 3: Correlations

\begin{tabular}{|l|l|l|l|l|l|}
\hline \multicolumn{2}{|c|}{} & $\begin{array}{l}\text { SNS } \\
\text { reliance }\end{array}$ & $\begin{array}{l}\text { Political } \\
\text { efficacy }\end{array}$ & $\begin{array}{l}\text { Political } \\
\text { knowledge }\end{array}$ & $\begin{array}{l}\text { Interest in } \\
\text { politics }\end{array}$ \\
\hline SNS reliance & $\begin{array}{l}\text { Pearson } \\
\text { correlation }\end{array}$ & 1 & .024 & .006 & .065 \\
\cline { 2 - 6 } & Sig. (2-tailed) & & .613 & .890 & .184 \\
\hline
\end{tabular}

**. Correlation is significant at the 0.01 level (2-tailed).

Political interest, political knowledge and political efficacy are all important factors of political participation, with political interest having the highest impact on political participation; however, the analysis (Table 3 ) does not reveal any statistically significant relationship between reliance on SNS and these political variables.

\section{DISCUSSION}

The study set out to investigate the role of social media in youth political participation. The evidence points to an increasing importance of social media in the political processes. Further, SNSs are a useful campaign tool but have a limited level of impact and influence on political participation and the campaign process.

As witnessed in the 2016 US presidential campaigns and the 2013 general elections and 2017 campaigns in Kenya, SNSs provide an easily accessible medium for the absorption and distribution of campaign information, allowing campaign strategists to easily target voters, recruit volunteers, mobilise support, update on scheduled events and to report on campaign activities (Enjolras, Steen-Johnsen and Wollebaek 2010; Gueorguieva 2008; Smith 2013; Ubayasiri 2008; Utz 2009).

The study results revealed that reliance on SNSs is positively related to political participation. SNSs indeed have a significant though not huge influence on politics and the political campaigning process. This is manifested through political engagement, evaluation of issue appeals, levels of political information efficacy, civic engagement, political interest, political trust, political efficacy and political participation (Gueorguieva 2008; Williams and Gulati 2007; 2008). Some previous studies in the US found no significant impact of SNSs on political participation or on the political variables (Baumgartner and Morris 2009; Zhang et al. 2010).

Unfortunately, as seen with the 2016 US elections, SNSs have also been blamed for the rise and spread of "fake news" and misinformation. The social media platforms 
facilitated the rapid flow of false stories which some people blamed for the election of Donald Trump (Allcott and Gentzkow 2017). It is also not always easy to authenticate the accuracy of information on SNSs (Marchi 2012).

Generally, political discussions on SNSs are highly partisan and polarised with a tendency to oversimplify complex issues. Additionally, SNSs tends to create echo chambers where people with similar views are insulated from opposing views. This makes it hard to have vibrant debate or reasonable discussion of issues which aids in informed decision making (Silverman 2016; Sunstein 2009).

Successful campaigns effectively integrate social media as an important part of campaigning, supplemented by offline campaigning as evidenced by Obama in 2008 (Wilcox 2010). Political acts on SNSs are an addition to an individual's engagement rather than an alternative to other political activities. An overreliance on social media is not likely to achieve much if not supported by an effective ground game to support the online campaigns. Online support does not always translate into offline support, specific efforts have to be made to transform this virtual support into ballot box support. The goal must be to generate a response from social media activity that will translate into actual support among voters (Hwang 2016).

The study underscores the capacity of SNSs to facilitate political discussions. Most young people engage in political discussions through posting political information, commenting on other people's political status, commenting on videos and other links on social media (Clarke 2010; Smith 2013; Thelwall, Wilkinson and Uppal 2009). In this sense, SNS create an online public sphere where citizens (young people) engage in discussion of political issues (Dewing 2010; Westling 2007).

The potential of SNSs to mobilise for political action is not in doubt as evidenced by their rapid adoption and integration in political campaigns across the globe. However, this promise and potential that social media will radically transform political participation is yet to be realised as seen in this and other related studies.

\section{CONCLUSION}

It is clear from this study that SNSs help to mobilise specific demographic segments within society by creating a new platform for political mobilisation which works alongside traditional structures of mobilisation. This means that SNSs will continue to play a central role in the political campaigning processes.

The study has proven that SNSs are useful in enhancing political knowledge, facilitating political discussions among users, enabling interaction between voters and candidates, diffusion of political messages and propaganda, targeting voters with campaign information and supporting offline campaign efforts all targeted at influencing voters' political decision at the ballot. This influence is manifested in limited political engagement, evaluation of issue appeals, levels of political information efficacy, political interest, political trust and political efficacy. 
While SNSs do not seem to have a major direct impact on political choices among the users, they are important in shaping and driving public opinion, guiding online conversations, amplifying political messages and spreading negative propaganda messages. While SNSs have not replaced the existing traditional structures of political campaigning and mobilisation, campaign strategists and politicians cannot ignore the opportunity provided by SNSs in the voter mobilisation process.

\section{LIMITATIONS}

The current study had several limitations.

1. The sample of undergraduate students is unique and their political habits are definitely not generalisable to the broader Kenyan population. However, it provides important insights into political habits and experiences of young people when they engage in politics through social media.

2. Internet and social media penetration levels are still relatively low in Kenya with only about 32 per cent of the Kenyan population having access to the internet (CCK 2013) and about 15 per cent on Facebook.

3. Social media platforms keep evolving. The study primarily focused on Facebook, Twitter and YouTube. Other social media platforms like WhatsApp also play a role in political mobilisation.

4. The study was carried out immediately after the Kenyan elections, when views and participation levels were more heightened than they would have been outside campaign or electoral season.

\section{REFERENCES}

Allcott, H., and M. Gentzkow. 2017. Social Media and Fake News in the 2016 Election (No. w23089). Cambridge, MA: National Bureau of Economic Research.

BAKE (Bloggers Association of Kenya). 2015. "The State of Blogging and Social Media in Kenya Report." http://www.monitor.co.ke/2015/06/16/the-state-of-blogging-social-media-in-kenya-report-download

Barbour, H., S. Bradshaw, A. Fleischer, G. McCall, and Z. Fonalledas. 2013. "Growth and Opportunity Project." http://growthopp.gop.com/default.aspx

Bauerlein, M. 2008. The Dumbest Generation: How the Digital Age Stupefies Young Americans and Jeopardizes Our Future (or, Don't Trust Anyone Under 30). New York: Tarcher/Penguin.

Baumgartner, J. C, and J. S. Morris. 2009. "MyFaceTube Politics: Social Networking Websites and Political Engagement of Young Adults." Social Science Computer Review 24 (1): 24-44. 
BBCAfrique. 2015."Facebook ouvre un bureau enAfrique.”www.bbc.com/afrique/region/2015/06/150630_ facebook

Bimber, B., and R. Davis. 2003. Campaigning Online: The Internet in US Elections. Oxford and New York: Oxford University Press.

Boyd, D. M., and N. B. Ellison. 2007. "Social Network Sites: Definition, History, and Scholarship." Journal of Computer-Mediated Communication 13 (1): 210-230.

Calhoun, C. 1992. Introduction: Habermas and the Public Sphere. Cambridge, MA: MIT Press.

CCK (Communications Commission of Kenya). 2013. "Quarterly Sector Statistics Report - Fourth Quarter of the Financial Year 2012/13." http://www.ca.go.ke/images/downloads/STATISTICS/Sector\%20 Statistics\%20Report\%20Q4\%202012-13.pdf

Clarke, A. 2010. Social Media: Political Uses and Implications for Representative Democracy. Ottawa: Library of Parliament.

Cohen, C. J., and J. Kahne. 2011. "Participatory Politics. New Media and Youth Political Action.” Oakland: YPP Research Network.

Dalton, R. J. 2008. "Citizenship Norms and the Expansion of Political Participation.” Political Studies 56 (1): 76-98.

Delli Carpini, M. X. 2000. "Gen.com: Youth, Civic Engagement, and the New Information Environment." Political Communication 17 (4): 341-349.

Dewing, M. 2010. Social Media: An Introduction. Ottawa: Library of Parliament.

Dryzek, J. S. 2000. Deliberative Democracy and Beyond: Liberals, Critics, Contestations. Oxford: Oxford University Press.

Enjolras, B., K. Steen-Johnsen, and D. Wollebæk. 2013. "How Do Social Media Change the Conditions for Civic and Political Mobilization?" In Social Media and Politics: Online Social Networking and Political Communication in Asia, edited by P. Behnke. Singapore: Konrad-Adenauer-Stiftung.

Feldman, O., and K. Kawakami. 1991. "Media Use as Predictors of Political Behavior: The Case of Japan." Political Psychology 12: 65-80.

Gastil, J., and P. Levine, eds. 2005. The Deliberative Democracy Handbook: Strategies for Effective Civic Engagement in the 21st Century. San Francisco: Jossey-Bass.

Gestrich, A. 2006. "The Public Sphere and the Habermas Debate." German History 24 (3): 413-430.

Gimmler, A. 2001. "Deliberative Democracy, the Public Sphere and the Internet." Philosophy and Social Criticism 27 (4): 21-39.

Gray, R., J. Vitak, E. W. Easton, and N. B. Ellison. 2013. "Examining Social Adjustment to College in the Age of Social Media: Factors Influencing Successful Transitions and Persistence." Computers and Education 67: 193-207. 
Gueorguieva, V. 2008. "Voters, Myspace, and Youtube: The Impact of Alternative Communication Channels on the 2006 Election Cycle and Beyond." Social Science Computer Review 26 (3): 288-300.

Habermas, J. [1962] 1989. The Structural Transformation of the Public Sphere. Cambridge, MA: MIT Press

Habermas, J. 1988. On the Logic of the Social Sciences. Translated by S. W. Nicholsen and J. A. Stark. Cambridge, MA: MIT Press.

Hwang, A. S. 2016. "Social Media and the Future of US Presidential Campaigning." CMC Senior Theses. Paper 231.

ITU. 2015. ICT Facts and Figures. www.itu.int/en/ITU-D/Statistics

Kellner, D. 1989. Jean Baudrillard: From Marxism to Postmodernism and Beyond. Stanford: Stanford University Press.

Kellner, D. 2000. "Habermas, Public Sphere and Democracy: A Critical Intervention." In Perspectives on Habermas, edited by L. E. Hanne, 259-288. Peru, IL: Open Court.

KNBS (Kenya National Bureau of Statistics). 2014. Kenya Facts and Figures.

Kushin, M. J., and M. Yamamoto. 2010. "Did Social Media Really Matter? College Students' Use of Online Media and Political Decision Making in the 2008 Election.” Mass Communication and Society 13 (5): 608-630.

Lenhart, A. 2009. "The Democratization of Online Social Networks." Washington: Pew Internet and American Life Project. http://www.pewinternet.org/2009/10/08/the-democratization-of-onlinesocial-networks

Marchi, R. 2012. "With Facebook, Blogs, and Fake News, Teens Reject Journalistic 'Objectivity". Journal of Communication Inquiry 36 (3): 246-262.

Min, S. J. 2007. "Online vs. Face-to-Face Deliberation: Effects on Civic Engagement." Journal of Computer*Mediated Communication 12 (4): 1369-1387.

Mitchell, A., J. Gottfried, and K. E. Matsa. 2015. Millennials and Political News: Social Media - the Local $T V$ for the Next Generation? Washington: Pew Research Center. http://www.pewresearch.org/fact$\operatorname{tank} / 2015 / 06 / 01 /$ political-news-habits-by-generation

Mutz, D. C., and P. S. Martin 2001. "Facilitating Communication Across Lines of Political Difference: The Role of Mass Media." American Political Science Review 95: 97-114.

Perrin, A. 2015. Social Media Usage: 2005-2015. Washington: Pew Research Center. http://www. pewinternet.org/2015/10/08/social-networking-usage-2005-2015

Rainie, L., and A. Smith. 2012. Politics on Social Networking Sites. Washington: Pew Research Center Internet and American Life Project. http://www.pewinternet.org/...media/.../2012/PIP PoliticalLifeonSocialNetworkingSites.pdf

Safranek, R. 2012. "The Emerging Role of Social Media in Political and Regime Change." ProQuest Discovery Guides. http://www.csa.com.discoveryguides/ 
Shirky, C. 2011. "The Political Power of Social Media.” Foreign Affairs 90 (1): 28-41.

Silverman, C. 2016. "This Analysis Shows how Fake Election News Stories Outperformed Real News on Facebook." https://www.buzzfeed.com/craigsilverman/viral-fake-election-news-outperformed-realnews-on-facebook?utm_term=.jid5nbpYmR\#.gi48E394ZR

Smith, A. 2009. Online Participation in the Social Media Era. Washington: Pew Internet and American Life Project.

Smith, A. 2013. Civic Engagement in the Digital Age. Washington: Pew Internet and American Life Project.

Steinfield, C., N. B. Ellison, and C. Lampe. 2008. "Social Capital, Self-Esteem, and Use of Online Social Network Sites: A Longitudinal Analysis." Journal of Applied Developmental Psychology 29 (6): 434-445.

Storck, M. 2011. "The Role of Social Media in Political Mobilisation: A Case Study of the January 2011 Egyptian Uprising." MA dissertation, University of St Andrews.

Strandberg, K. 2013. "A Social Media Revolution or Just a Case of History Repeating Itself? The Use of Social Media in the 2011 Finnish Parliamentary Elections." New Media and Society 15 (8): 13291347.

Šuminas, A., 2010. Politicians in Social Media: New Forms of Communication. Jaunuju Mokslininku Darbai 1 (26): 235-240.

Šuminas, A., and A. Mierzecka. 2014. "Political Information Sources for Young Citizens: A Case Study of Lithuanian Youth Information Behavior." Informacijos Mokslai 70: 25-44.

Sunstein, C. 2002. Republic.com. Princeton: Princeton University Press.

Sunstein, C. R. 2009. Going to Extremes: How Like Minds Unite and Divide. Oxford: Oxford University Press.

Tedesco, J. C. 2007. "Examining Internet Interactivity Effects on Young Adult Political Information Efficacy." American Behavioral Scientist 50 (9): 1183-1194.

Thelwall, M., D. Wilkinson, and S. Uppal. 2010. "Data Mining Emotion in Social Network Communication: Gender Differences in MySpace." Journal of the American Society for Information Science and Technology 61 (1): 190-199.

Tumasjan, A., T. O. Sprenger, P. G. Sandner, and I. M. Welpe. 2010. "Election Forecasts with Twitter: How 140 Characters Reflect the Political Landscape.” Social Science Computer Review 29 (4): 402-418.

Utz, S. 2009. "The (Potential) Benefits of Campaigning via Social Network Sites." Journal of ComputerMediated Communication 14 (2): 221-243.

Walmsley, A. 2008. “Andrew Walmsley on Digital: Campaigning 2.0 Could Swing UK Vote." http://www. campaignlive.co.uk/article/andrew-walmsley-digital-campaigning-20-swing-uk-vote/835401?src_ site=marketingmagazine 
Westling, M. 2007. "Expanding the Public Sphere: The Impact of Facebook on Political Communication." http://www.thenewvernacular.com/projects/facebook_and_political_communication.pdf

Wilcox, M. 2010. “Parties Campaign like It's 1999.” Ottawa Citizen.

Williams, C. B., and G. J. Gulati. 2007. "Social Networks in Political Campaigns: Facebook and the 2006 Midterm Elections." Annual Meeting of the American Political Science Association 1 (1): 49-62.

Williams, C. B., and G. J. Gulati. 2008. What is a Social Network Worth? Facebook and Vote Share in the 2008 Presidential Primaries. Washington: American Political Science Association.

Young, I. M. 2000. Democracy and Inclusion. New York: Oxford University Press.

Zhang, W., T. J. Johnson, T. Seltzer, and S. L. Bichard. 2010. "The Revolution Will Be Networked: The Influence of Social Networking Sites on Political Attitudes and Behavior." Social Science Computer Review 28 (1): 75-92. 